\title{
Economic Protection of Secure Operation and Development of Companies in the Rocket and Space Industry
}

\author{
Aleksandr Mikhaylovich Batkovskiy1 \\ Yuriy Nikolayevich Makarov2 \\ Elena Georgievna Semenova ${ }^{3}$ \\ Alena Vladimirovna Fomina ${ }^{1}$ \\ Evgenii lurevich Khrustalev ${ }^{4}$ \\ ${ }^{1}$ Joint Stock Company "Central Research Institute of Economy, Management and Information Systems "Electronics", \\ Moscow, Russian Federation \\ ${ }^{2}$ Federal Space Agency, Moscow, Russian Federation \\ ${ }^{3}$ The Department of Innovation and Quality Management, St. Petersburg State University of Aerospace Instrumentation, \\ St. Petersburg, Russian Federation \\ ${ }^{4}$ Central Economics and Mathematics Institute of the Russian Academy of Sciences, Moscow, Russian Federation \\ Email: batkovskiy_a@instel.ru
}

Doi:10.5901/mjss.2015.v6n4s4p414

\section{Abstract}

\begin{abstract}
This article describes theoretical fundamentals and the most rational approaches to establishment of the economic protection system for business entities in the Russian space industry in the current geopolitical environment. This research focuses on non-stationary business environment, in which enterprises of the Russian rocket and space industry operate. The applied methods are based on the economic analysis theory and mathematical tools of the probability theory, project management theory, mathematical statistics, economic and mathematical modeling. The main features of the space industry (which is a high-tech industry) include huge innovation capacity, sophisticated system of pass-through financing from various sources, development and production within complete life cycle of high-tech products, high R\&D costs as compared to the national resources. This article shows that sustainability of company's operations depends on the company's ability to adapt to changes in the external and internal business environment, to face such changes and to maintain a dynamic equilibrium of company's operations in accordance with current and prospective goals and tasks. Based on the above, various approaches to operation and estimation of the integral indicator of financial and economic sustainability (security) of high-tech companies are considered and analyzed. The following risk management measures are offered for development planning in rocket and space companies: multivariate planning method and plans adjustment methods; financial resources provisioning method; evasion method, which rejects too risky projects.
\end{abstract}

Keywords: economic security, risks, assessment, rocket and space industry, indicators, operations, companies.

\section{Introduction}

Utilization of rocket and space technologies shows that technological modernization, sophistication of high-tech products, operation of the space industry in volatile and uncertain research, production, financial and economic environments is accompanied by increase of various risks (Kachalov, R.M., 2012). Additional conditions result in the need for reconsideration of the estimated costs of economic protection (including insurance services, as compensation and risks coverage steps) and accounting for relevant indicators when estimating the costs of state programs (Bohnert, A. et al., 2015). Yet, in order to improve performance, we need to analyze risks and threats, emerging (with certain degree of certainty) in the course of implementation of space programs and projects (Dadalko, W.A. and Pitulko, S.Y., 2010), as well as to study state-of-the-art efficient institutional arrangements, financial and economic tools applied globally in order to cover relevant risks (including those related to operations of the space industry).

This research focuses on the non-stationary business environment, in which companies of the Russian rocket and space industry operate, and which is known for its weak predictability and uncertainty of its current and prospective condition, as well as high levels of business, research and technological risks generated by these factors, related to those space operations which are very sophisticated and significant for the national economy and defense (Kachalov, R.M., 2014). 
The importance of this study is determined by: the critical condition of R\&D, technological and production capacity of the national rocket and space industry; the need for improvement in its competitiveness in the context of globalization of space operations and severe competition in space exploration; demand for long-term economic security of companies engaged in rockets and space engineering and practical application of the results (Kotov, A.N. et al., 2008).

The main purpose of the expected research results is to elaborate institutional arrangements and economic tools and methods of risk management or mitigation in order to improve feasibility of Russian space programs and projects with account for:

- financial and other resource restrictions faced by individual companies and the rocket and space industry in general;

- $\quad$ production capacities of companies in the rocket and space industry and related industries;

- main types of risks and threats to the economic sustainability (security) of companies;

- condition and current trends in development of the Russian rocket and space industry;

- state-of-the-art global experience of space operations.

Therefore, this research focuses on consideration of the methodological fundamentals of estimates of the financial and economic sustainability of high-tech companies in the Russian rocket and space industry, study of common trends of their development and the preconditions for improvement in their operational efficiency.

This research applied the methods based on the economic analysis theory and mathematical tools of the probability theory, project management theory, mathematical statistics, economic and mathematical modeling (Miorando R.F. et al., 2014). The analytical part of the research is based on the materials describing development of rocket and space technologies, condition of companies of the rocket and space industry (Gruntman, M., 2014). Besides, the authors relied on their long-term research experience in relevant institutions, and they also applied research results achieved during recent years by various research institutions of the Russian Academy of Sciences (Livshits, W.N., 2013).

\section{Literature Review}

We should proceed from the premise that the rocket and space industry is the basic element of the national capacity for space operations; this industry possesses high-tech facilities and products, innovation capacity, efficient realization of which significantly affects development of the Russian economy (Payson, D.B., 2010). This is supported by the results of numerous studies conducted in many developed countries. For example, study of the history of development of China's $R \& D$ activities in space exploration shows exceptional significance of the rocket and satellite sectors of the rocket and space industry for innovative development of the Chinese economy (Erickson, A.S., 2014). The main features of space operations (which represent a high-tech industry) include:

- $\quad$ high innovation capacity comprising R\&D (including fundamental research and development), design and technological capacities, research, experimental and production facilities, skilled researchers and engineers required for creation of new types of products and technologies;

- sophisticated system of pass-through financing from various sources, full life cycle development and production of high-tech products, taking into account the multilevel cooperation ties; long duration of innovative and production cycle (up to several years); related problems of product's payback period, working capital financing and debt repayment under the conditions of high levels of uncertainty and R\&D risks;

- high costs (as compared to available national resources) of many new R\&D projects, requiring state's contribution to establishment of research institutions and portfolios of successful research projects, maintenance of existing research, technological, production and HR capacity, elimination of the technological gap etc.

The above peculiarities of the rocket and space industry distinguish it (in respect of the operating environment, economic and organizational condition of high-tech facilities) from the whole range of other industries, when considering the methodological aspects of assessment of its own financial and economic sustainability (security) and the impact of its performance on the national security in general (Raikunov, G.G., 2010).

We should also mention that solution of the problem of providing relevant financial and economic resources for implementation of technology development programs in the rocket and space industry is complicated by the need to process significantly larger (as compared with previous information requirements for feasibility assessment) amount of information (retrospective data and projections on financing of development programs, on completed and current projects, on companies, including their business and financial operations, research, technological and HR capacities, the costs of not just final products, but also the costs of their components). This requires development of a unified integrated database and special information tools on the basis of state-of-the-art computer technologies (Fliege, J. et al., 2013). 
The commercial component of space operations is experiencing dynamic development, tourism segments of the space economy emerge, allowing to raise more financing and improve the economic security of the rocket and space industry due to the fees paid for space flights (Chang, Y.-W., 2015). New uses of space stations for solution of important research and technological issues also require expansion in many types of equipment used in the rocket and space industry, as well as creation of new devices for full scale experiments (Gruntman, M., 2014).

Figure 1 shows the structure of space operations as the subject matter of systemic studies (Makarov, Y.N. and Khrustalev, E.Iu., 2010).

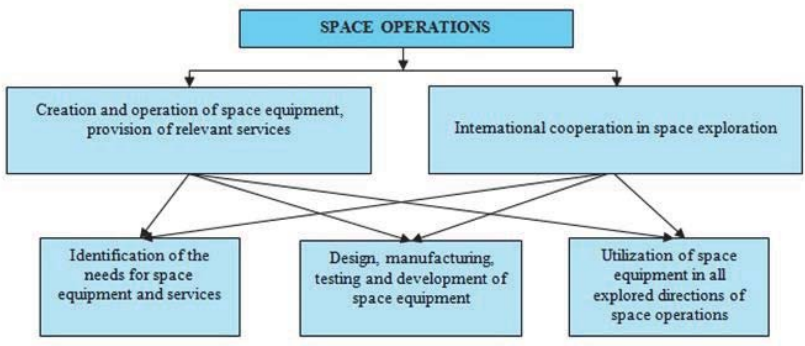

Figure 1. Structural representation of space operations

\section{Methods}

Moving towards the issues of the national economic security strategy, we should mention that this strategy, while setting goals and specifying its objects, includes: description of external and internal threats to the national economic security; identification and monitoring of factors, contributing to strengthening or destruction of the sustainability of the country's social and economic position in the short- and mid-term (3-5 years); identification of criteria and parameters (thresholds) of indicators, which describe the national economic interests and meet the economic security requirements; development of economic policies, including institutional transformations, the methods used in accounting for the factors affecting the situation with economic security; directions of government's steps towards implementation of the strategy.

Assessment of financial and economic security in high-tech industries is important, primarily, due to the fact that their actively utilized capacities represent a determining stabilizing factor of the anti-crisis development, ensuring economic growth and national economic independence and security (Slavyanov, A.S., 2011). Deterioration in the capacity results in hardly foreseeable consequences of deindustrialization of the federal state, in which the multi-branch and a highly integrated industry (as opposed to regional separation of resource and raw material industries and disintegration trends in respect of the common economic area) is one of the strongest means for enhancing its integrity (Golichenko, O.G., 2011).

In order to provide for an efficient economic security of the rocket and space industry, we should identify external and internal threats, as well as a set of the contributing factors (Table 1).

Table 1. Threats and their contributing factors

\begin{tabular}{|c|c|}
\hline Threats to economic security & Factors contributing to the threat \\
\hline $\begin{array}{l}\text { Inefficient and distorted structure of the } \\
\text { economy }\end{array}$ & $\begin{array}{l}\text { - resource and raw materials specialization of the economy, high level of monopolization } \\
\text { - low competitiveness of most products, } \\
\text { - degradation of production, research, technological and HR capacity } \\
\text { - production decline and loss of domestic and global markets for high-tech products } \\
\text { - poor protection of national manufacturers } \\
\text { - dramatic strengthening of foreign manufacturers' positions in the domestic market, } \\
\text { - high external and internal debt. }\end{array}$ \\
\hline Widening household wealth gap & $\begin{array}{l}\text { - stratification of the society, increase in the percentage of poor population, } \\
\text { - growth of unemployment, } \\
\text { - delinquent payroll liabilities, } \\
\text { - company shutdowns. }\end{array}$ \\
\hline $\begin{array}{l}\text { Increasing inequality in regional social } \\
\text { and economic development }\end{array}$ & $\begin{array}{l}\text { - objective differences in regional development levels; depressed and backward areas, } \\
\text { - disruption in production and technological ties between enterprises, } \\
\text { - widening gap between per capita national income levels faced by various regions of the Russian } \\
\text { Federation. }\end{array}$ \\
\hline $\begin{array}{l}\text { Criminalization of the society and } \\
\text { economy }\end{array}$ & $\begin{array}{l}\text { - crime growth, } \\
\text { - penetration of criminals into government agencies, merging of criminals and government, } \\
\text { - weakening of the government control system in the domestic financial market, in privatization, trade, } \\
\text { export and import operations. }\end{array}$ \\
\hline
\end{tabular}


Despite the fact that, in general, the issues of economic security assessment are formulated and studied by a number of authors, detailed guidelines (which take into account the industry-level specifics of production facilities on the regional, corporate and company levels, where they are needed the most) are not so efficient and diverse, because they apply only specialized approaches, usually ignoring the generalized systems of criteria, indicators of financial and economic sustainability (Livshits, W.N. and Livshits, S.W., 2011).

Therefore, one of definitive requirements to strategic planning in high-tech industries at the current stage of development includes not just the need for feasibility studies focusing on resource management efficiency (with excess production capacities, this complex criterion ceases to be self-sufficient and important), but also the criteria and parameters of economic security, identification of steps focusing on preservation of existing capacity, first of all search for additional financial sources, as well as competition methods and strengthening of positions in various segments of the domestic and international markets for high-tech products (Wilenskii, P.L. et al., 2008).

In this respect, the following ways of survival, direct and indirect state support of high-tech industries (including those which refer to space operations) will be useful:

- expansion in application of new financial technologies in our economy, establishment of venture funds etc., permission to finance technological development through investment of a part of generated non-taxable income into new developments and production facilities;

- tax deferrals in case of delayed payment for fulfilled public contracts;

- $\quad$ investment tax credits to the buyers (i.e. to consumers rather than producers, since granting of tax credits to producers turned out to be inefficient) of high-tech products and services, including syndicated loans repayable out of income generated from use of the above products and services;

- establishment of the procedure guaranteeing to the companies which possess the core and most important technologies (so called 'critical technologies') a certain percentage of income from operation and use of products made under relevant public contracts by highly profitable commercial organizations (e.g., operators of communication and navigation systems etc.);

- exemption (full or partial, for a certain period) of high-tech industries from federal and/or local taxes, when such measure prevents decline in production, contributes to preservation and creation of new jobs;

- payment of a percentage of income generated by use of products of high-tech companies to special development accounts of such companies rather than to the pool of state budget revenues;

- permission granted to publicly owned high-tech companies to dispose of excessive liquid technological equipment and facilities in accordance with established procedure for the purposes of their own development;

- change in existing bankruptcy procedure and termination of bankruptcy procedure in respect of high-tech enterprises and facilities, which serve, primarily, the military and industrial complex, since it destroys existing technical cooperation;

- protection of domestic manufacturers which are able to supply (on a totally new level) sophisticated products (first of all, electronics, other household appliances and office equipment) to the domestic market;

- support of various forms of production and financial integration of Russian manufacturers and foreign corporations, implementation of protectionism policies in promotion of Russian products in the global market;

- establishment of the system for dissemination of research, technical and technological knowledge, providing incentives for transfer of advanced technologies from the military-industrial complex to non-defense industries;

- fostering and stimulation of the demand for goods and services as the basis for restoration of financial, HT, research and production capacity of high-tech companies;

- retention of skilled employees, training and engagement of young professionals.

\section{Results}

Main research results, which are considered in this article, may be systematized as follows.

1. Completed analysis of various approaches to estimation of the integral indicator of financial and economic sustainability (security) of a high-tech company. If the graphical approach shown in Figure 2 is used, then such criterion of whether a company meets economic security requirements would be represented by condition $S_{H}$ $\geq S_{n k} \geq S_{k p}$, where $S_{H}$ is the area of a polygon in normal or pre-crisis production development; $S_{n k}$ means the polygon area in crisis or threshold production zone; $S_{k p}$ means the polygon area in a critical production condition zone. 


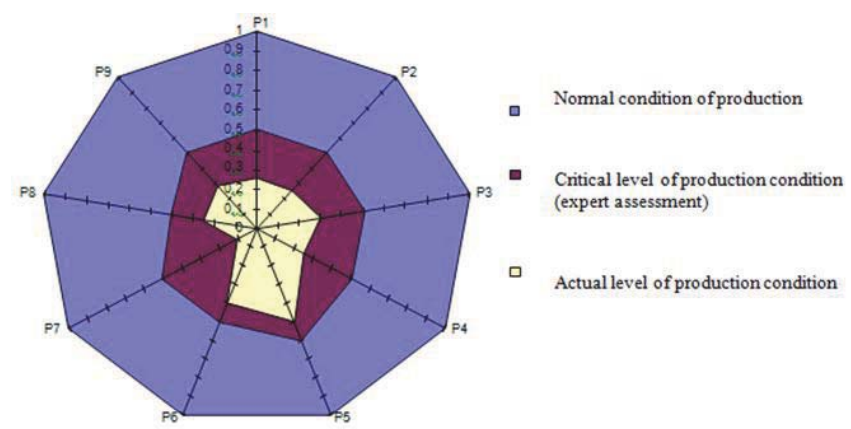

Figure 2. Diagram of the indicators of financial and economic security condition

2. Let's illustrate qualitative analysis of financial and economic security condition using the case of high-tech engineering industry, which may be described by certain system of security indicators under normal conditions of operation, threshold parameters (indicator values) of critical condition level and the indicators of actual condition (Table 2).

Table 2. Indicators and values of the industry's financial and economic security

\begin{tabular}{|l|c|c|c|c|c|}
\hline Indicators of financial and economic security & & $\begin{array}{l}\text { Indicator value under } \\
\text { a normal condition, \% }\end{array}$ & $\begin{array}{c}\text { Normal production } \\
\text { condition }\end{array}$ & $\begin{array}{c}\text { Critical production } \\
\text { condition (expert } \\
\text { assessment) }\end{array}$ & $\begin{array}{c}\text { Actual production } \\
\text { condition }\end{array}$ \\
\hline Amount of working capital financing etc. & $\mathrm{P}_{1}$ & 100 & 1 & 0,5 & 0,25 \\
\hline Production capacity utilization & $\mathrm{P}_{2}$ & 100 & 1 & 0,5 & 0,25 \\
\hline Profitability & $\mathrm{P}_{3}$ & 100 & 1 & 0,5 & 0,3 \\
\hline Percentage of R\&D in total operations & $\mathrm{P}_{4}$ & 40 & 1 & 0,5 & 0,25 \\
\hline Percentage of research in total R\&D & $\mathrm{P}_{5}$ & 20 & 1 & 0,6 & 0,5 \\
\hline Salary as compared to the average sale in the industry & $\mathrm{P}_{6}$ & $150-200$ & 1 & 0,5 & 0,4 \\
\hline Fixed assets replacement rate & $\mathrm{P}_{7}$ & $10-13$ & 1 & 0,5 & 0,1 \\
\hline Percentage of employees aged 50+ & $\mathrm{P}_{8}$ & 20 & 1 & 0,4 & 0,25 \\
\hline Percentage of equipment with up to 10 years life cycle & $\mathrm{P}_{9}$ & 70 & 1 & 0,5 & 0,28 \\
\hline
\end{tabular}

In order to estimate deviations, the indicators' values were normalized against the values of indicators of facility's normal operation (which equal 1); threshold values of financial and economic security indicators and the values of actual condition indicators are estimated as unit fractions. Then, for example, full utilization of a production facility in a stationary operating condition would be equal to 1 , and the threshold value of an indicator for the critical level of economic security would be equal to 0.5 ; actual utilization would amount to 0.25 . The system of actual condition indicators is arranged on the basis of the public data, averaged based on the results and conditions of high-tech industries' operation.

3. We applied a balanced comprehensive approach to sustainability of a company (in its capacity of a production system), which takes into account not just financial, but also other aspects of its socioeconomic condition, subject to changes in the course of continuing evolution of business relationships.

Financial and economic security of a company is described by the system of specially selected technical and economic indicators of its operations, the values and ranges of which (under the conditions of disturbances within the company's internal and external environment, which do not disrupt its production function) are taken as standard; any breaches in limits are considered as factors preventing efficient business operations and development. Sustainability of company's operations depends on the company's ability to adapt to changes in the external and internal business environment, to face such changes and to maintain a dynamic equilibrium of company's operations in accordance with current and prospective goals and tasks.

4. At the same time, we should accept the argument regarding the counterproductiveness of the two extremes: hyper-sustainability and permanent volatility of the developing system. If hyper-sustainability does not allow the system to upgrade and develop on the upward path, then permanent volatility complicates fixation within the system of new acquired properties ensuring the system's viability under dynamic business conditions.

5. Figure 3 shows the main problems faced by most companies of the rocket and space industry, and which can 
not be overcome by most disadvantaged companies in the rocket and space industry; Figure 3 also shows the main reasons for emergence of such problems (successful companies have similar problems, but they have the ability and capacity to deal with them).

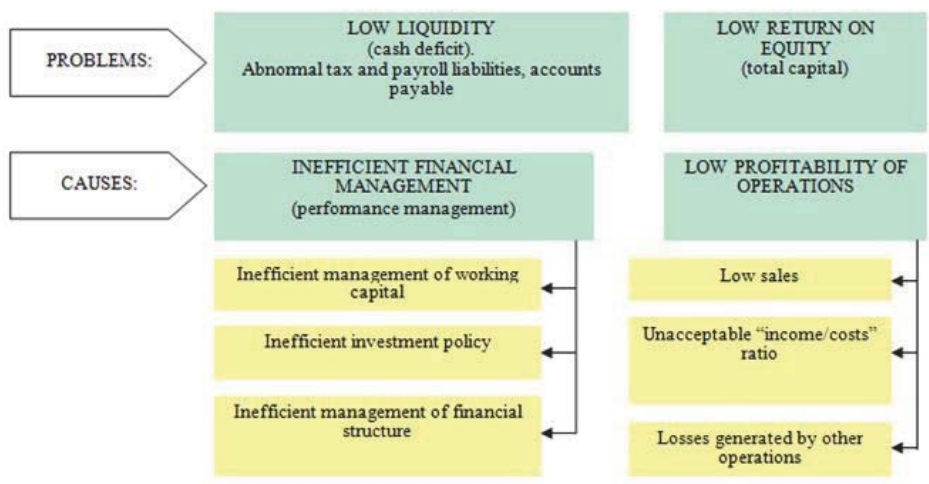

Figure 3. Main problems with financial condition of high-tech companies

The deficit of net working capital is the main adverse factor faced by almost all companies. Even the most financially successful companies face the deficit of cash required for financing of production and business operations. Attempts to increase current expenses at the cost of depreciation expense will result in early wear-and-tear of plant and equipment and prevent all kinds of innovations. Passive investment policy will lead to irreversible processes - further deterioration in competitiveness and destruction of facilities due to obsolescence and wear-and-tear of equipment, machines, infrastructure.

\section{Discussion}

Risk management. Any concept is based on an intention, from the perspective of which a phenomenon is considered. The main intention of this work is to consider the production-related and economic support for implementation of rocket and space technology planning as a risky, but still a controlled process. These aspects are interdependent, which allows to reduce plan implementation management (under the existing conditions) to management of risk occurring due to various factors (Platon, V. et al., 2014).

We consider risk management by relevant management bodies as a system of institutional arrangements, economic tools and methods focusing on identification, assessment and prevention (in a timely manner) of events of occasional and unpredictable nature, which may disrupt normal implementation of programs and plans regarding development of technologies in the rocket and space industry, as well as focusing on risk mitigation during the plan drafting and implementation phases. Therefore, the risk management task may be broken down into two interrelated processes: analysis of possible types of risk and assessment of their value; risk management (Ebert, S., 2014).

In the conceptual context, the above two processes should be not just interconnected, but they also should be based on the principles of goal programming in order to secure efficient implementation of the plans for technology development in the rocket and space industry.

Until recently, the issue of development of risk assessment and management methods did not receive sufficient attention when drafting and implementing the plans for technology development in the rocket and space industry. Risks of their implementation were assessed just intuitively and, in most cases, there were no special risk mitigation strategy. Quite often, the efforts of developers of such programs and plans focused on elimination of consequences of adverse events rather than prevention of such events, which, of course, is not the best way of deal with uncertainty (damage prevention costs are approximately 30 times less than damage indemnity costs).

Need for quantitative risk assessment. Analysis revealed that application of existing risk assessment and management methods is theoretically possible for improvement in goal programming efficiency in respect of the rocket and space technologies; however, in most cases, this requires their significant modification with account for the specific features of rocket and space technologies, as well as the projects and plans of their creation, since such plans are based 
on achievement of national security-related goals and elimination of waste of government money rather than just generation of profits. Main risk management methods on the rocket and space technology planning phase are as follows.

Holding competitions for identification of the most efficient project developer. Holding of a design competition in order to create one rocket and space technology model based on several designs. Design competition allows to improve model development chances, but brings additional costs. That's why selection of the type of the competition for model development purpose is based on the minimum mathematical expectation of full costs.

Multi-option planning. The multi-option planning method and plan adjustment method (being the versions of the risk mitigation method), deal with development of several plan options during the phase of long-term plan development, selection of options based on the "efficiency-cost" criterion and transformation of the program's option for development of rocket and space technologies during the phase of drafting of the short-term plan in case of significant deviation of available financing from its target levels adopted when developing relevant plans and programs.

Financing. Financial resource allocation method (since financial resources are the most mobile type of resources). The 'planned reserves' concept (i.e. the planned set of resources diverted from current production and non-production consumption) was used in development of methodological tools and institutional arrangements for improvement in R\&D planning efficiency. 'Required probability of R\&D plan realization' and 'relative error of required and allocated funds projections' concepts were introduced; we show that in order to compensate possible excess of the actual cost of the rocket and space technology models, the planned reserve of the long-term plan should amount to $10-20 \%$ of allocated funds (with the required probability being equal to 0.9). However, other types of risks of planned works and the potential damage are not taken into account.

Identification of particularly risky projects. Evasion method, which rejects projects, the implementation of which is connected with significant risk. It should be applied with caution to orders for rocket and space technology, because it may result in failure to fulfill the planned tasks, the solution of which relied on the models which were expected to be created within such projects. In the best case scenario, this task could be solved by other means, but with significantly less effect or significantly larger resource requirements, including financial resources.

Risk insurance methodology. In this context, we should emphasize the increasing role of risk insurance method as a type of the evasion method, the application of which (until recently) was inefficient and rare in the practice of rocket and space technology goal programming. There are several reasons for that:

- $\quad$ underdevelopment of acceptable types of insurance in the country;

- insufficient authorized capitals and insurance reserves of domestic insurers, which do not allow to cover significant risks intrinsic to rocket and space services and technologies (especially R\&D);

- absence of a reasonable strategy for state support of insurance for the benefit of the Federal Space Agency;

- absence of the legal and regulatory framework for insurance of orders in the rocket and space industry;

- deficit of insurers' data required for estimation of the insured value;

- absence of developers' rocket and space technology plans and insurers' methodological framework for assessment of rocket and space technology creation risks and for assessment of insurance funds;

- insufficient cash flows to pay insurance premiums.

At the same time, insurance methods have been actively developed recently in our country and abroad (Jevtic, P. and Regis, L., 2015). In Russia, the quantity of insurers grows together with expansion in large project insurance opportunities. The experience of insurance against exports, transportation, construction and installation operations risks, maritime and space risks etc. is already in place. In this regard, it is the right time to create a comprehensive insurance system providing for insurance of orders in the rocket and space industry by contractors and customers.

Absence of comprehensive and consistent approach to risk management. Taking into account the foregoing, absence of a comprehensive approach to application of all methods when drafting and implementing rocket and space technology plans may be specified as a common disadvantage of existing methodological approaches to risk assessment and management. Besides, the problem of creation of a system of institutional arrangements and economic tools, which allow to conduct relevant risk management policy, remains unconsidered. Many mechanisms of such type are already available and contribute to solving of other tasks related to improvement in Russia's national security. However, in order to enhance the research, production and economic infrastructure for implementation of rocket and space technology plans, they are used to a very limited extent.

Insurance types. Insurance of space operations seems to be an important problem which directly affects investment attractiveness and further development of the space industry (Krichevskiy, N.A., 2005). In order to achieve positive results, successful global practices of comprehensive insurance should be used, with account for the Russian environment, which includes increased risks, imperfect legislation, lack of experience, secrecy (Pradhan, R.P. et al., 2015). Investment risks may be reduced by insuring the whole life cycle of space industry investment projects with 
engagement of a specialized insurance broker.

Risk insurance includes the following types of insurance coverage: various types of property insurance; liability insurance; life insurance, the main details of which are shown below.

Property insurance in the space industry. Such type of insurance focuses on manufacturers of space equipment, transport and the space industry, which represents a set of functionally interrelated orbital and earth-based facilities intended for resolution of military, research or economic tasks in the space or from the space, and also intended for fulfillment of such tasks within the space system.

Property insurance should be divided into two types of insurance - insurance of space vehicles and the launch sites, manufacturers, transport. Destruction of such expensive facilities as launch sites may adversely affect development of the entire rocket and space industry.

The amounts of insurance proceeds under such insurance type are determined on the basis of the cost of the space vehicle and land facilities, which may be damaged in case of the insured event.

Liability insurance. Liability insurance in the space industry covers: professional liability of technical staff, developers, designers and other professionals, whose fault may result in an insured event; liability for causing damage to life, health or property of legal entities and individuals in case of fall or unsuccessful launch of space vehicles; liability for causing damage to natural complexes, environmental pollution.

Main threats to individuals and legal entities include fall of rocket parts (stages) beyond the estimated areas and fall of space vehicles during descend, or fall from the orbit. The physical impact of falling rocket parts is usually aggravated by significant damage to the environment, because the rocket stages contain significant amounts of toxic fuel, while fallen satellites may have radioactive elements.Space industry facilities - such as transport infrastructure, pipelines, rocket fuel plants, radar stations etc. - also pose a threat to the environment.

That's why, liability insurance is broken down into such insurance types as insurance of liability of companies, which operate hazardous production facilities, insurance of liability for environmental pollution and insurance of liability for the damage inflicted by space objects.

Liability insurance protects an insured against financial costs which it may incur when facing claims for indemnification of damage inflicted to third parties, and liability insurance also protects the interests of third parties, since the responsible party might not have sufficient funds to compensate the damage.

Insurance proceeds (liability limits) under such type of insurance are paid on the basis of estimated maximum possible damage, which may be inflicted to a third party in case of emergency launches of space vehicles, accidents during transportation of fuel and rocket components, accidents on space industry facilities.Potential damage is estimated in accordance with flying paths of launch vehicles carrying the space vehicles, with account for the type and toxicity of used fuel and the space vehicle's type.

Life insurance. This type of insurance covers life and health of space vehicle's crew, operational personnel at launch sites, testing and installation stands. Life insurance of the crew is an obligatory element of comprehensive insurance in the space industry, and it is maintained through all phases of space and prelaunch preparation and the space flight itself. Upon successful completion of a flight, life insurance agreement should be maintained during the whole period required for identification of hidden health damage. Operational staff should also be insured for the period of employment for the manufacturers of space vehicles and launch sites.

\section{Conclusion}

The need to eliminate existing conflicts between the deterministic approach to rocket and space technology planning and increased uncertainty of creation of the production and economic infrastructure for fulfillment of orders for rocket and space products requires formation of a new concept of program and plan management implementation on the basis of accounting and management of risk emerging due to financial, economic, research, technical, production and technological factors (Cornell, A., 2011). The technical aspect of such infrastructure focuses on minimization of the consequences of development of adverse events, leading to reduced efficiency of tasks resolved by the Russian Federal Space Agency (Buzykin, W.I. et al., 2007). The economic component allows to avoid waste of money in case of an adverse event. Main research results, conclusions and suggestions may be stated as follows:

- institutional arrangements, financial and economic tools, methodological approaches to economic protection of companies of the rocket and space industry which implement space programs and projects (domestic or international), facing threats resulting from volatility of research, production, financial and economic environment in Russia and abroad, were analyzed;

- suggestions regarding application of relevant approaches, models, institutional arrangements, financial and 
economic tools, as well as successful international practices in the system of comprehensive economic protection of national space programs and projects, were developed;

- optimal approaches to creation of the economic protection system were studied; optimal combination of financial and economic protection and recovery of damages (when rendering services and operating space industry facilities) was suggested (based on application of mathematical modeling tools and analysis of threats and risks, particularly in a volatile and uncertain business environment;

- financial sources and financial needs for recovery of damages in case of potential volatility and uncertainty of research, production, financial and economic environments were suggested for implementation of space programs and projects;

- the probabilistic nature of funds allocation and efficiency of their application in implementation of rocket and space technology planning requires a wider use of the economic categories of provisioning and risk insurance when justifying and implementing relevant programs, plans and projects. The study of the essence, role, common and specific features of reserve and insurance funds allows to conclude that implementation of such forms of distributional relationships represents one of the most important directions of enhancement of goal programming in the rocket and space technology development and improvement in feasibility of relevant state program and short-term plans.

- study and consolidation of existing domestic methodological tools and institutional arrangements for risk assessment and management revealed the following: such methods demonstrated their highest development in investment project feasibility studies on the basis of the 'acceptable risk' concept (which depends on the investor's risk appetite); domestic methods used in assessment of the rocket and space technology planning risk are fragmentary and focus just on separate projects included in the plan and specific types of risk, without assessment of potential damage; a comprehensive approach needs to be developed for application of the entire set of existing methods when drafting and implementing rocket and space technology plans.

\section{Acknowledgements}

This research project was supported by the Russian Scientific Fund (RSF Project No. 14-18-00519).

\section{References}

Bohnert, A., Gatzert, N., \& Jorgensen, P. (2015). On the Management of Life Insurance Company Risk by Strategic Choice of Product Mix, Investment Strategy and Surplus Appropriation Schemes. Insurance: Mathematics And Economics, 60, 83-97.

Buzykin, V.I., Davyidyuk A.N., \& Kotov, A.N. (2007) Raketno-kosmicheskaya promyishlennost Rossii [Rocket and space Industry in Russia]. Moscow: TsNTI "Poisk" [in Russian].

Chang, Y.-W. (2015). The first decade of commercial space tourism. Acta Astronautica, Vol. 108, March-April 2015, 79-91.

Cornell, A. (2011). Five Key Turning Points in the American Space Industry in the Past 20 years: Structure, Innovation, and Globalization Shifts in the Space Sector. Acta Astronautica, 69 z (11-12), 1123-1131.

Gruntman, M. (2014). Advanced degrees in astronautical engineering for the space industry. Acta Astronautica, Vol. 103, OctoberNovember 2014, 92-105.

Dadalko, V.A., \& Pitulko, S.Yu. (2010) Ekonomicheskaya bezopasnost aerokosmicheskoy otrasli Rossii [The economic security of Russian aerospace industry]. Minsk: IVTs Minfina.

Ebert, S. (2015). On Skewed Risks in Economic Models and Experiments. Journal Of Economic Behavior \& Organization, 112, 85-97.

Erickson, A.S. (2014). China's space development history: A comparison of the rocket and satellite sectors. Acta Astronautica, Vol. 103, October-November 2014, 142-167.

Fliege, J., \& Kaparis, \& K., Khosravi, B. (2013). Operations research in the space industry. European Journal of Operational Research, Vol. 217, Issue 2, March 2013, 233-240.

Golichenko, O.G. (2011) Osnovnyie faktoryi razvitiya natsionalnoy innovatsionnoy sistemyi [The Main Factors of Development of the National Innovation System]. Moscow: Nauka [in Russian].

Gruntman, M. (2014). Advanced Degrees in Astronautical Engineering for the Space Industry. Acta Astronautica, 103, 92-105.

Jevtic, P., \& Regis, L. Assessing the Solvency of Insurance Portfolios via a Continuous Time Cohort Model. SSRN Journal, 61, 36-47.

Kachalov, R.M. (2014) Fenomen ekonomicheskogo riska $v$ institutsionalnom prostranstve: sistemnyiy analiz [The Phenomenon of Economic Risk in the Institutional Space: System Analysis]. Moscow: Izdatelstvo Finuniversiteta [in Russian].

Kachalov, R.M. (2012) Upravlenie ekonomicheskim riskom: Teoreticheskie osnovyi i prilozheniya [Economic Risk Management: Theoretical Foundations and Applications]. Sankt-Peterburg: Nestor-Istoriya [in Russian].

Kotov\& A.N., \& Payson, D.B. (2008) Perspektivyi razvitiya raketno-kosmicheskoy promyishlennosti s uchetom provodimoy innovatsionnoy politiki v strane i mezhdunarodnoy kosmicheskoy deyatelnosti Rossii [Prospects for the Development of Space Industry in View of Ongoing Innovation Policy in the Country and International Space Activities of Russia]. Moscow: ZAO "NII 


\section{"ENTSITEH" [in Russian].}

Krichevskiy, N.A. (2005) Strahovanie investitsiy: Upravlenie investitsionnyimi riskami, modeli kombinirovannogo strahovaniya, razvitie strahovogo investirovaniya [Investment Insurance: Investment Risk Management, Comprehensive Insurance Model, the Development of Investment Insurance]. Moscow: Dashkov \& Co [in Russian].

Livshits, V.N. (2013) Sistemnyiy analiz rynochnogo reformirovaniya nestatsionarnoy ekonomiki Rossii (1992-2013) [System analysis of market reform of the non-stationary economy of Russia (1992-2013)]. Moscow: LENAND [in Russian].

Livshits, V.N., \& Livshits, S.V. (2011) Sistemnyiy analiz nestatsionarnoy ekonomiki Rossii (1992-2010): ryinochnyie reformyi, krizis, investitsionnaya politika [System Analysis of Non-Stationary Economy of Russia (1992-2010): Market Reforms, Crisis, and Investment Policy]. Moscow: Maroseyka [in Russian].

Makarov, Yu.N., \& Hrustalev, E.Yu. (2010) Mehanizmy restrukturizatsii naukoemkih proizvodstv (na primere raketno-kosmicheskoy promyishlennosti) [Mechanisms of restructuring of science-intensive industries (for example, aerospace industry)]. Ekonomika $i$ matematicheskie metodyi - Economics and Mathematical Methods, 46 (3), 31 - 42 [in Russian].

Miorando, R., Ribeiro, J., \& Cortimiglia, M. (2014). An economic-probabilistic model for risk analysis in technological innovation projects. Technovation, 34(8), 485-498.

Payson, D.B. (2013) Kosmicheskaya deyatelnost: evolyutsiya, organizatsiya, institutyi [Space Activities: Evolution, Organizations, Institutions]. Moscow: Knizhnyiy Dom "LIBROKOM" [in Russian].

Platon, V., Frone, S., \& Constantinescu, A. (2014). Financial and Economic Risks to Public Projects. Procedia Economics And Finance, 8, 204-210.

Raikunov, G.G. (2010) Razvitie mirovoy kosmonavtiki v XXI veke [Development of world space industry in the XXI century]. Moscow: RTSoft [in Russian].

Pradhan, R., Arvin, M. \& Norman, N. (2015). Insurance development and the finance-growth nexus: Evidence from 34 OECD countries. Journal of Multinational Financial Management, 31, 1-22.

Slavyanov, A.S. (2011) Problemyi finansirovaniya meropriyatiy po ekonomicheskoy zaschite prioritetnyh innovatsionnyih proektov [Problems of Funding of Activities for Economic Protection of Priority Innovative Projects]. Modeli i metody innovatsionnoy ekonomiki - Models and methods of the innovation economy Vol. 3 [in Russian].

Wilenskii, P.L., Livshits, W.N., \& Smolyak, S.A. (2008) Otsenka effektivnosti investitsionnyh proektov. Teoriya i praktika [Evaluation of the Effectiveness of Investment Projects. Theory and Practice]. Moscow: Delo [in Russian]. 